\title{
Relationship between plasma propranolol concentration and relief of essential tremor
}

\author{
D. JEF F ER SON, P. JEN NER, A N D C. D. MAR S D N \\ From the University Department of Neurology, Institute of Psychiatry and King's College \\ Hospital Medical School, London
}

\begin{abstract}
SUMMARY The relationship between plasma propranolol concentration and relief of essential tremor was examined in 11 patients during treatment with oral racemic propranolol in doses of 30 to $640 \mathrm{mg} /$ day. Although propranolol decreased tremor in all 11 patients, the degree of improvement varied widely in individuals (mean $51 \%$, range $25-90 \%$ ), and was not related directly to the plasma propranolol concentration. In seven patients, optimum reduction in tremor occurred at plasma propranolol concentrations below $20 \mathrm{ng} / \mathrm{ml}(0.077 \mu \mathrm{mol} / \mathrm{l})$ and, in three others, below $40 \mathrm{ng} / \mathrm{ml}(0.154 \mu \mathrm{mol} / \mathrm{l})$. It is concluded that the optimum response of essential tremor to propranolol is achieved at relatively low plasma propranolol levels, levels which are obtained by daily propranolol doses of $120-240 \mathrm{mg}$.
\end{abstract}

Essential tremor has been regarded as an exaggerated form of physiological tremor (Marshall, 1962), often inherited as an autosomal dominant trait, and exhibiting a characteristic and unexplained sensitivity to ethanol (Growdon et al., 1975). Marsden et al. (1967) showed that racemic propranolol (Inderal, ICI) was capable of decreasing physiological tremor of the hands by an action on peripheral $\beta$-adrenoreceptors in muscle (Marsden and Meadows, 1970) and muscle spindles (Hodgson et al., 1969). Subsequently, a number of studies indicated that racemic propranolol has a beneficial effect in benign essential tremor (Winkler and Young, 1971; Dupont et al., 1973; Morgan et al., 1973; Winkler and Young, 1974; Tolosa and Loewenson, 1975; Young et al., 1975).

However, the response of tremor to propranolol in individual patients is variable, and some workers have concluded that the drug is no more effective than placebo (Foster et al., 1973; Sweet et al., 1974). Since there is a wide variation in the plasma propranolol concentration in different individuals after the same oral dose (Nies and Shand, 1975), it is possible that variations in the clinical response of essential tremor to the drug are related to individual patients achieving dif-

\footnotetext{
Address for reprint requests: Professor C. D. Marsden, University Department of Neurology, Institute of Psychiatry, De Crespigny Park, London SES 8AL.

Accepted 12 March 1979
}

ferent plasma propranolol concentrations on the same dose.

In a recent study of essential tremor, in which propranolol was given intravenously, it was concluded that suppression of tremor was related to plasma propranolol concentration and that maximum tremor suppression was achieved at plasma propranolol levels of $80-100 \mathrm{ng} / \mathrm{ml} \quad(0.309$ $0.386 \mu \mathrm{mol} / \mathrm{l}$ ) (McAllister et al., 1977). The present study, therefore, was undertaken to examine the relationship between tremor suppression and plasma propranolol concentration during oral medication. A preliminary report of this work was given to the British Pharmacological Society (Jefferson et al., 1979).

\section{Patients and methods}

Eleven patients with moderately disabling essential tremor were studied. The diagnosis of essential tremor was made on the basis of a characteristic postural tremor of the upper limbs and sometimes also of the head but without other neurological abnormalities. All patients had normal thyroid, cardiac, renal, and hepatic function, and had previously reported a favourable response of their tremor to propranolol. The main clinical features of the patients are presented in Table 1 .

Patients were assessed at two-weekly intervals over a period of approximately three months; at 
Table 1 Clinical details of 11 patients with essential tremor

\begin{tabular}{rllll}
\hline Patient & $\begin{array}{c}\text { Age } \\
(y r)\end{array}$ & Sex & $\begin{array}{l}\text { Family } \\
\text { history }\end{array}$ & $\begin{array}{l}\text { Length of } \\
\text { history } \\
(y r)\end{array}$ \\
\hline 1 & 40 & M & - & 10 \\
2 & 73 & F & + & 50 \\
3 & 66 & M & - & 16 \\
4 & 44 & F & + & 6 \\
5 & 31 & F & + & 17 \\
6 & 59 & M & + & 34 \\
7 & 45 & F & - & 4 \\
8 & 57 & F & + & 7 \\
9 & 62 & F & + & 30 \\
10 & 56 & F & + & 10 \\
11 & 50 & F & & \\
\hline
\end{tabular}

each visit each patient was prescribed a different dose of racemic propranolol (Inderal, ICI) or placebo, on a single-blind basis. Medication was given in three or four divided daily doses, ranging from $30-640 \mathrm{mg}$ propranolol a day. The maximum dose achieved in individual patients was determined by the occurrence of side effects, and compliance was assessed by counting the number of tablets which remained in the container at the end of each two-week period.

At each visit the patients were assessed clinically by the same examiner (DJ) in the same surroundings, and any side effects encountered during medication were recorded. After a 10 minute period of rest lying flat, the supine and standing pulse rate and blood pressure were measured. Tremor during a number of manual tests was scored objectively by rating each test on a scale from $0-5$, and a "total tremor score" was obtained from the sum of the scores achieved in the individual tests. Objective assessment of tremor was made by visual rating of the tremor of the outstretched hands, handwriting, spiral and sinusoid drawings, and by scoring a timed performance test which involved threading rings on to a peg. The tests of handwriting and drawing were rated independently by two observers (DJ and CDM), the latter rating the samples without knowing the patients' medication. There was a close correlation between the ratings of the two observers of the tests of handwriting and drawing $(r=0.94)$. Patients were also asked to rate the severity of their own tremor by marking a $100 \mathrm{~mm}$ linear scale, thus providing a "subjective tremor score" at each visit.

Venous blood was withdrawn at the end of the clinical examination, within two to four hours after the preceding dose, and the plasma propranolol concentration was assayed using a fluorimetric technique (Offerhaus and van der
Vecht, 1976). The threshold for drug detection was $5 \mathrm{ng} / \mathrm{ml}(0.019 \mu \mathrm{mol} / \mathrm{l})$ and the technique measured $(+)$ and $(-)$ propranolol. Serial blood samples were taken over a 12 hour period from one patient who had been treated with $120 \mathrm{mg}$ propranolol daily for two weeks in order to examine the fluctuations in plasma propranolol concentrations during the day.

\section{Results}

Patient compliance, as assessed by tablet counting at each visit, was excellent, and side effects from propranolol were not reported when the daily intake was below $120 \mathrm{mg}$. Above this dose, three patients complained of lassitude and one other patient developed nocturnal hallucinations which remitted spontaneously after three nights and did not recur despite a subsequent increase in the daily propranolol intake to $640 \mathrm{mg}$. No patients reported symptoms of hypotension during the study.

In the patient studied over a 12 hour period (Fig. - 1), plasma propranolol concentrations reached peak values approximately two hours after each oral dose and, during the day, there was a wide fluctuation in the plasma propranolol levels, findings which are similar to those reported by Vervloet et al. (1977).

Peak plasma propranolol concentrations also showed a wide variation among the 11 patients when they were taking the same daily oral dose of propranolol (Fig. 2). For example, at a daily intake of $120 \mathrm{mg}$ of propranolol the plasma levels ranged from $8-210 \mathrm{ng} / \mathrm{ml}(0.031-0.811 \mu \mathrm{mol} / \mathrm{l})$.

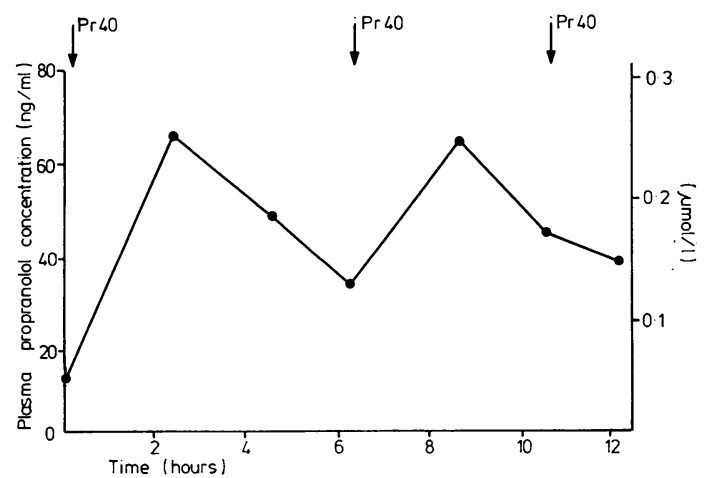

Fig. 1 Fluctuation in the plasma propranolol concentration over a 12 hour period in a subject (patient 10) maintained on $120 \mathrm{mg}$ daily of propranolol by mouth. Ordinates: plasma propranolol concentration in $\mathrm{ng} / \mathrm{ml}$ and $\mu \mathrm{mol} / \mathrm{l}$; abscissa: time in hours. Arrows indicate times of oral administration of propranolol $40 \mathrm{mg}$ (Pr40). 


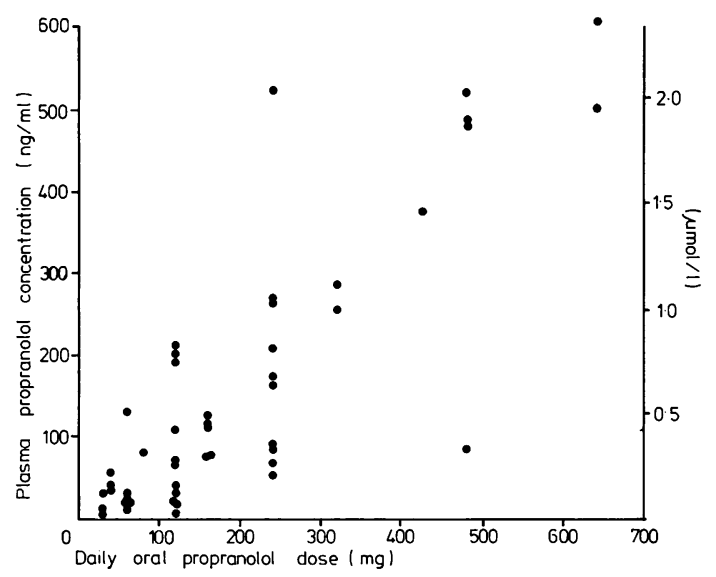

Fig. 2 Plasma propranolol concentrations during different daily maintenance doses of oral propranolol in 11 patients with essential tremor. Blood samples withdrawn two to four hours after previous oral propranolol dose. Ordinates: plasma propranolol concentration in $\mathrm{ng} / \mathrm{ml}$ and $\mu \mathrm{mol} / \mathrm{l}$; abscissa: daily oral propranolol dose, $\mathrm{mg}$.

In individuals, however, there was a linear correlation between the daily propranolol dose and the plasma level measured two to four hours after medication, as shown in Fig. 3, where the values obtained in five patients who tolerated a wide range of doses are presented.

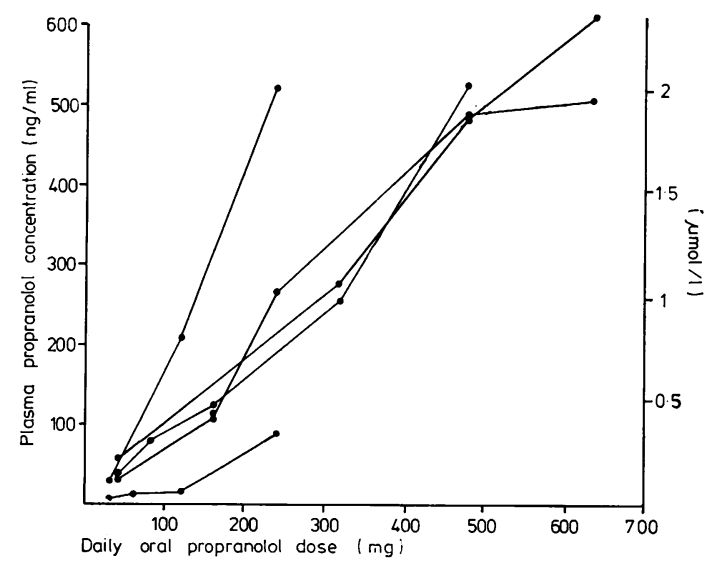

Fig. 3 Plasma propranolol concentrations in five patients with essential tremor at different daily oral doses of propranolol. Blood samples withdrawn two to four hours after previous propranolol dose. Ordinates: plasma propranolol concentrations in $\mathrm{ng} / \mathrm{ml}$ and $\mu \mathrm{mol} / \mathrm{l}$; abscissa: daily oral propranolol dose, $m g$.
By altering the daily dose, all patients achieved at least one plasma propranolol concentration below and at least one above $40 \mathrm{ng} / \mathrm{ml}$ $(0.154 \mu \mathrm{mol} / \mathrm{l})$ making it possible to compare the response of tremor at low and high plasma propranolol levels with that of placebo.

BLOOD PRESSURE AND PULSE RATE (FIGS. 4 AND 5) Supine and standing diastolic blood pressures were unaffected by propranolol when compared with placebo. Supine systolic blood pressure was unaffected at plasma propranolol concentrations below $40 \mathrm{ng} / \mathrm{ml}$ but was reduced at plasma levels above $40 \mathrm{ng} / \mathrm{ml}(0.154 \mu \mathrm{mol} / \mathrm{l})$ compared with placebo $(P<0.01)$. Standing systolic blood pressure was reduced at plasma propranolol concentrations below and above $40 \mathrm{ng} / \mathrm{ml}(0.154 \mu \mathrm{mol} / \mathrm{l}) \mathrm{com}$ pared with placebo $(\mathrm{P}<0.05)$, but there was no difference between the mean reductions in blood pressure below and above $40 \mathrm{ng} / \mathrm{ml}$.

There was a marked reduction in the supine pulse rate during treatment with propranolol $(P<0.001)$, but there was no difference between the supine pulse rates at plasma propranolol concentrations below and above $40 \mathrm{ng} / \mathrm{ml}$ $(0.154 \mu \mathrm{mol} / 1)$. Standing pulse rate was reduced at plasma propranolol concentrations below $40 \mathrm{ng} / \mathrm{ml}$ compared with placebo $(\mathrm{P}<0.001)$, but there was an even greater reduction in the standing pulse rate at plasma levels above $40 \mathrm{ng} / \mathrm{ml}(\mathrm{P}<0.01)$.

\section{TREMOR}

When the total objective tremor scores were examined (Table 2), all patients showed an improvement in their score during medication with propranolol $(\mathrm{P}<0.001)$, the maximum improvement ranging from $25-90 \%$ (mean $51 \%$ ). There was no difference between the scores achieved at the lower and higher plasma propranolol levels. These findings were confirmed by the subjective tremor scores recorded by the patients (Table 3).

Seven patients, with a plasma propranolol concentration below $20 \mathrm{ng} / \mathrm{ml}(0.077 \mu \mathrm{mol} / \mathrm{l})$ showed a reduction in tremor of $10-80 \%$ compared with placebo $(P<0.02)$, but failed to show further tremor suppression at higher plasma propranolol concentrations (Fig. 6). Three other patients achieved maximal, or near maximal, tremor suppression at plasma propranolol levels of $40 \mathrm{ng} / \mathrm{ml}$ $(0.154 \mu \mathrm{mol} / 1)$ or less. Only one patient appeared to gain additional benefit from increasing plasma propranolol levels up to or above $100 \mathrm{ng} / \mathrm{ml}$ $(0.386 \mu \mathrm{mol} / 1)$, but even she relapsed when the level was further increased to $500 \mathrm{ng} / \mathrm{ml}$ (1.931 $\mu \mathrm{mol} / \mathrm{l})$. 


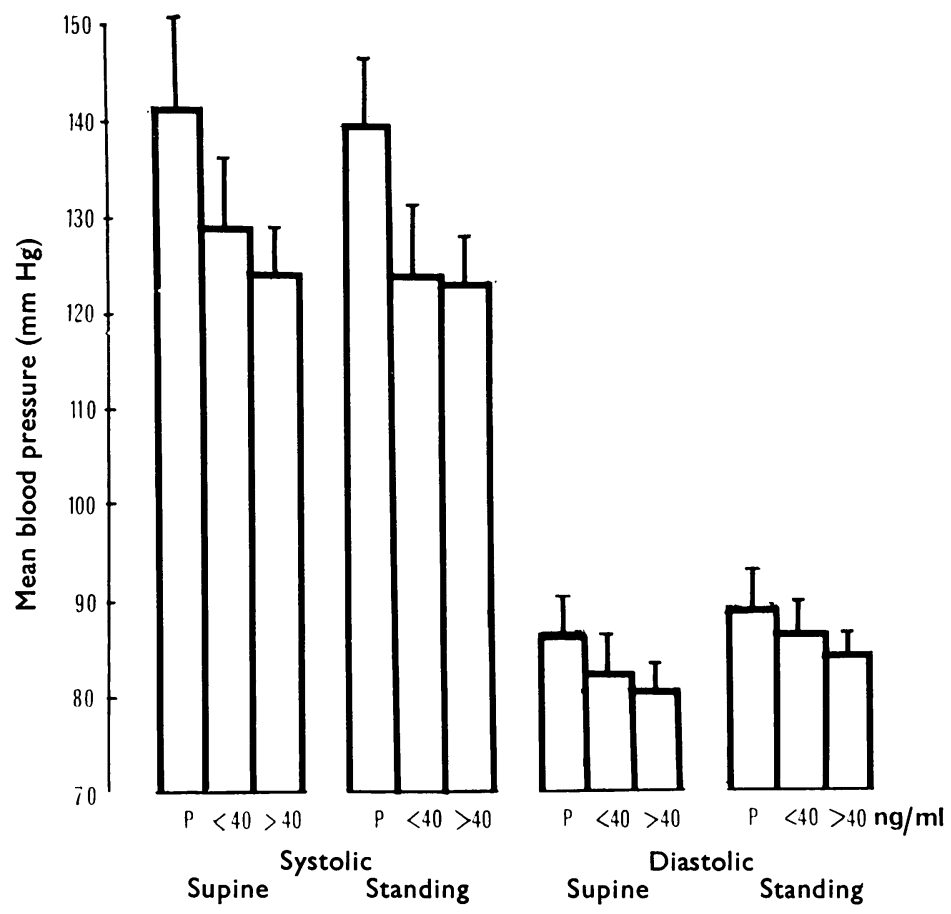

Fig. 4 Mean supine and standing systolic and diastolic blood pressures $+S E$ (bar) in 11 patients with essential tremor during treatment with placebo $(P)$ and propranolol at plasma concentrations below and above $40 \mathrm{ng} / \mathrm{ml}(0.154 \mu \mathrm{mol} / \mathrm{l})$. Using Student's t test for paired data, supine systolic blood pressure is reduced compared with placebo only at plasma propranolol levels above $40 \mathrm{ng} / \mathrm{ml}$ $(P<0.01)$, while standing systolic blood pressure is reduced at plasma levels below $(P<0.05)$ and above $(P<0.01)$ $40 \mathrm{ng} / \mathrm{ml}$. There is no significant difference between diastolic blood pressures during medication with placebo and propranolol at plasma levels below or above $40 \mathrm{ng} / \mathrm{ml}$ $\left(0.1<_{\boldsymbol{P}}<0.05\right)$.

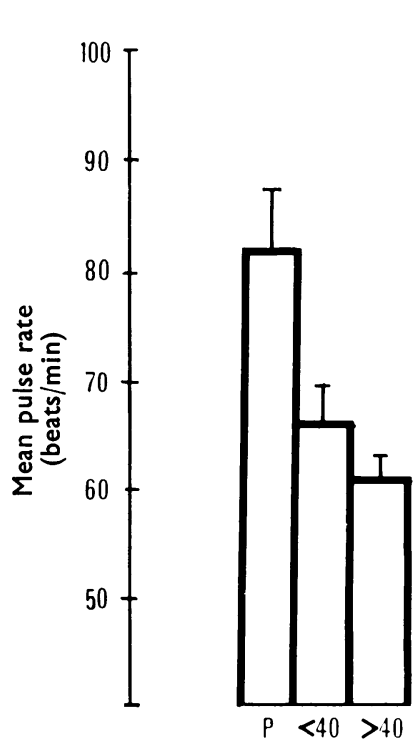

Supine

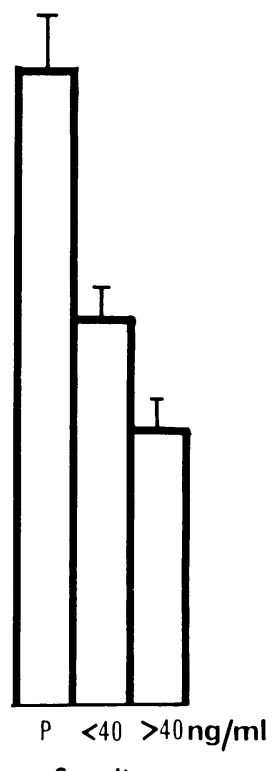

Standing
Fig. 5 Mean pulse rate $\pm S E$ (bar) in 11 patients with essential tremor during medication with placebo and propranolol at plasma concentrations below and above $40 \mathrm{ng} / \mathrm{ml}(0.154 \mu \mathrm{mol} / \mathrm{l})$. Using Student's $t$ test for paired data, both supine and standing pulse rates are reduced compared with placebo at low $(p<0.001)$ and high $\left({ }_{P}<0.001\right)$ plasma propranolol levels. The standing pulse rate is reduced more at plasma propranolol levels above $40 \mathrm{ng} / \mathrm{ml}$ than at plasma levels below $40 \mathrm{ng} / \mathrm{ml}\left(p^{\circ}<0.01\right)$. 
Table 2 Changes in total objective tremor scores during medication with placebo and propranolol at plasma levels below and above $40 \mathrm{ng} / \mathrm{ml}$

$(0.154 \mu \mathrm{mol} / \mathrm{l})$

\begin{tabular}{lccc}
\hline \multirow{2}{*}{\begin{tabular}{l} 
Patient \\
\cline { 3 - 4 }
\end{tabular}} & \multirow{2}{*}{ Placebo } & \multicolumn{2}{c}{ Plasma propranolol concentration } \\
\cline { 3 - 4 } & & $<40 \mathrm{ng} / \mathrm{ml}$ & $>40 \mathrm{ng} / \mathrm{ml}$ \\
\hline 1 & 20.0 & 7.0 & 12.0 \\
2 & 18.5 & 15.0 & 13.0 \\
3 & 17.0 & 13.0 & 11.0 \\
4 & 10.0 & 2.5 & 1.5 \\
5 & 11.0 & 4.0 & 8.5 \\
6 & 6.0 & 3.0 & 3.5 \\
7 & 12.0 & 12.0 & 7.9 \\
8 & 13.0 & 10.0 & 7.0 \\
9 & 12.0 & 10.0 & 9.8 \\
10 & 11.0 & 7.0 & 8.3 \\
11 & 7.0 & 3.5 & 4.0 \\
Mean score & 12.5 & 7.9 & 7.9 \\
SE & 1.33 & 1.32 & 1.1 \\
(Maximum tremor score $=25)$ & & \\
\hline
\end{tabular}

Tremor is reduced objectively at both low and high plasma propranolol levels (analysis of variance, $\mathrm{P}<0.001$ ) but there is no difference between the effects produced at the different plasma propranolol levels $(P>0.98)$.

Table 3 Patients' subjective tremor scores during medication with placebo and propranolol at plasma levels below and above $40 \mathrm{ng} / \mathrm{ml}(0.154 \mu \mathrm{mol} / \mathrm{l})$

\begin{tabular}{lccc}
\hline Patient & Placebo & \multicolumn{2}{c}{ Plasma propranolol concentration } \\
\cline { 3 - 4 } & & $<40 \mathrm{ng} / \mathrm{ml}$ & $>40 \mathrm{ng} / \mathrm{ml}$ \\
\hline 1 & 10.0 & 5.0 & 5.0 \\
2 & 8.5 & 10.0 & 7.4 \\
3 & 10.0 & 9.0 & 10.0 \\
4 & 5.5 & 2.8 & 0.0 \\
5 & 7.0 & 3.0 & 3.7 \\
6 & 9.0 & 4.5 & 5.5 \\
7 & 2.0 & 3.5 & 3.8 \\
8 & 9.5 & 7.5 & 7.5 \\
9 & 10.0 & 8.0 & 8.0 \\
10 & 6.0 & 4.8 & 4.5 \\
11 & 7.5 & 8.7 & 7.2 \\
Mean score & 7.7 & 6.1 & 5.7 \\
SE & 0.75 & 0.79 & 0.82 \\
(Maximum tremor score $=10)$ & &
\end{tabular}

Tremor is reduced subjectively at both the low and high plasma propranolol levels compared with placebo (analysis of variance, $P<0.02$ ) but there is no difference between the effects produced at the different plasma levels $(P<0.2)$.

\section{Discussion}

Optimum control of essential tremor during oral medication with propranolol occurred at much lower plasma propranolol levels (less than $40 \mathrm{ng} / \mathrm{ml}$ ) than those reported by McAllister et al . (1977) for intravenously administered propranolol (80-100 ng/ml (0.309-0.386 $\mu \mathrm{mol} / \mathrm{l}))$. Furthermore, there did not appear to be a linear correlation between tremor suppression and the logarithm of the plasma propranolol concentration over the range of $5-500 \mathrm{ng} / \mathrm{ml}(0.019-1.931 \mu \mathrm{mol} / \mathrm{l})$. Even though a greater reduction in the standing pulse

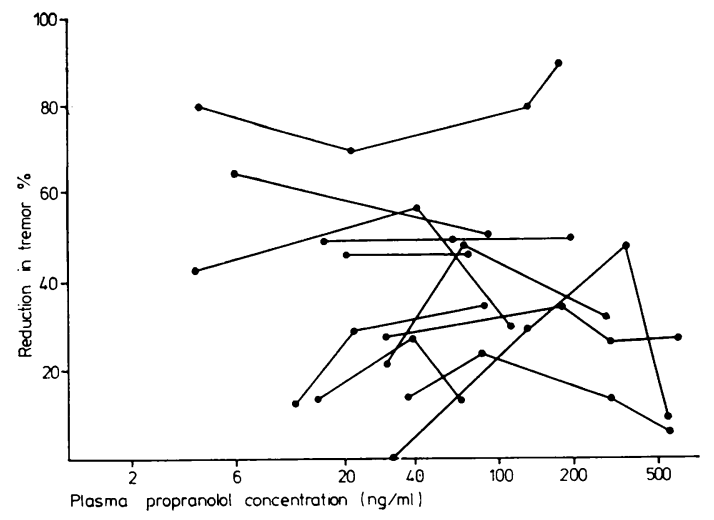

Fig. 6 Percentage reduction in tremor compared with placebo at different plasma propranolol concentrations in 11 patients with essential tremor. Ordinate:

percentage reduction in tremor; abscissa: plasma propranolol concentration in $\mathrm{ng} / \mathrm{ml}$ on log scale.

rate was seen at plasma propranolol levels above $40 \mathrm{ng} / \mathrm{ml}$, tremor suppression was equally effective at low and high plasma propranolol concentrations. While differences in the techniques used to assess tremor may account in part for the different results obtained in the present study compared with those of McAllister and his colleagues, it is possible that there may be a difference in the therapeutic effects of oral and intravenous propranolol. 4-Hydroxypropranolol, a metabolite with $\beta$-adrenoreceptor antagonist properties (Paterson et al., 1970; Cleaveland and Shand, 1972), is produced only after oral administration of propranolol and may, therefore, enhance the $\beta$ blocking effect of the drug. A difference between the effects of oral and intravenous propranolol was also noted by Coltart and Shand (1970) who found that about three times the plasma levels were required to block exercise-induced tachycardia after intravenous as against oral propranolol administration.

While several studies have demonstrated a linear relationship between the logarithm of the plasma propranolol concentration and the $\beta$ adrenoreceptor antagonist effect of the drug (Coltart and Shand, 1970; Paterson et al., 1970; Cleaveland and Shand, 1972; Pine et al., 1975; Baber and McAinsh, 1978), it is more difficult to establish a corresponding relationship between plasma levels and the therapeutic actions of the drug in various pathological conditions. Studies in hypertension (Hansson et al., 1974; Chidsey et al., 1975), angina pectoris (Pine et al., 1975), and cardiac arrhythmias (Coltart et al., 1971) have all shown great individual variations in the thera- 
peutically effective plasma propranolol levels. Furthermore, although it has been suggested that plasma propranolol concentrations of $40-100 \mathrm{ng} / \mathrm{ml}(0.154-0.386 \mu \mathrm{mol} / \mathrm{l})$ are required for optimum $\beta$-adrenergic blockade (Nies and Shand, 1975), several recent studies have shown that propranolol may also produce a high degree of $\beta$-adrenergic blockade at plasma levels below $20 \mathrm{ng} / \mathrm{ml}(0.077 \mu \mathrm{mol} / \mathrm{l})$ (Leonetti et al., 1975; Davies et al., 1978), findings which are supported in the present study.

It, therefore, appears that the wide range of individual responses of essential tremor to propranolol is not explained by different plasma propranolol concentrations achieved in individuals on the same dosage schedule. The critical difference between those patients who respond to propranolol and those that do not remains undetermined.

In conclusion, the results of the present study indicate that optimum suppression of essential tremor by propranolol occurs at relatively low plasma propranolol concentrations which are almost always achieved by daily doses of 120 $240 \mathrm{mg}$, and that it is not necessary to increase the dose of propranolol above such levels in the hope of achieving better control of the tremor.

\section{References}

Baber, N. S., and McAinsh, J. (1978). Low dose oral propranolol. Lancet, 1, 882.

Chidsey, C. A., Morselli, P., Morganti, A., Leonetti, G., and Zanchetti, A. (1975). Studies of the absorption and removal of propranolol in hypertensive patients during therapy. Circulation, 52, 313-318.

Cleaveland, C. R., and Shand, D. G. (1972). Effect of route of administration on the relationship between $\beta$-adrenergic blockade and plasma propranolol level. Clinical Pharmacology and Therapeutics, 13, 181185.

Coltart, D. J., and Shand, D. G. (1970). Plasma propranolol levels in the quantitative assessment of $\beta$-adrenergic blockade in man. British Medical Journal, 3, 731-734.

Coltart, D. J., Gibson, D. G., and Shand, D. G. (1971). Plasma propranolol levels associated with suppression of ventricular ectopic beats. British Medical Journal, 1, 490-491.

Davies, R., Morganti, A., Morselli, P. L., Pickering, T. G., Bianchetti, G., Romankiewicz, J., and Laragh, J. H. (1978). Beta-blockade and blood-levels after low-dose oral propranolol: the hepatic "first-pass" threshold revisited. Lancet, 1, 407-410.

Dupont, E., Hansen, H. J., and Dalby, M. A. (1973). Treatment of benign essential tremor with propranolol. Acta Neurologica Scandinavica, 49, 7584.
Foster, J. B., Longley, B. P., and Stewart-Wynne, E. G. (1973). Propranolol in essential tremor. Lancet, 1, 1455.

Growdon, J. H., Shahani, B. T., and Young, R. R. (1975). The effect of alcohol on essential tremor. Neurology (Minneapolis), 24, 259-262.

Hansson, L., Sweifler, A. J., Julius, S., and Ellis, C. N. (1974). Propranolol therapy in essential hypertension. Observations on predictability of therapeutic response. International Journal of Clinical Pharmacology, Therapy and Toxicology, 10, 78-89.

Hodgson, H. J. F., Marsden, C. D., and Meadows, J. C. (1969). The effect of adrenaline on the response to muscle vibration in man. Journal of Physiology, 202, 98-99P.

Jefferson, D., Jenner, P., and Marsden, C. D. (1979). Relationship between plasma propranolol levels and the clinical suppression of essential tremor. British Journal of Pharmacology, 7, 419-420P.

Leonetti, G., Mayer, G., Morganti, A., Terzoli, L., Zanchetti, A., Bianchetti, G., Di Salle, E., Morselli, P. L., and Chidsey, C. A. (1975). Hypotensive and renin-suppressing activities of propranolol in hypertensive patients. Clinical Science and Molecular Medicine, 48, 491-499.

Marsden, C. D., and Meadows, J. C. (1970). The effect of adrenaline on the contraction of human muscle. Journal of Physiology, 207, 429-448.

Marsden, C. D., Foley, T. H., Owen, D. A. L., and McAllister, R. G. (1967). Peripheral adrenergic receptors concerned with tremor. Clinical Science, 33, 53-65.

Marshall, J. (1962). Observations on essential tremor. Journal of Neurology, Neurosurgery, and Psychiatry, 25, 122-125.

McAllister, R. G., Markesbery, W. R., Ware, R. W., and Howell, M. A. (1977). Suppression of essential tremor by propranolol: correlation of effect with drug plasma level and intensity of beta-adrenergic blockade. Annals of Neurology, 1, 160-166.

Morgan, M. H., Hewer, R. L., and Cooper, R. (1973). Effect of the beta adrenergic blocking agent propranolol on essential tremor. Journal of Neurology, Neurosurgery, and Psychiatry, 36, 618-624.

Nies, A. S., and Shand, D. G. (1975). Clinical pharmacology of propranolol. Circulation, 52, 6-15.

Offerhaus, L., and van der Vecht, J. (1976). Improved fluorimetric assay of plasma propranolol. British Journal of Clinical Pharmacology, 3, 10611062.

Paterson, J. W., Conolly, M. E., Dollery, C. T., Hayes, A., and Cooper, R. G. (1970). The pharmacodynamics and metabolism of propranolol in man. Pharmacologica Clinica, 2, 127-133.

Pine, M., Favrot, L., Smith, S., McDonald, K., and Chidsey, C. A. (1975). Correlation of plasma propranolol concentration with therapeutic response in patients with angina pectoris. Circulation, 52, 886893.

Sweet, R. D., Blumberg, J., Lee, J. E., and McDowell, 
F. H. (1974). Propranolol treatment of essential tremor. Neurology (Minneapolis), 24, 64-67.

Tolosa, E. S., and Loewenson, R. B. (1975). Essential tremor: treatment with propranolol. Neurology (Minneapolis), 25, 1041-1044.

Vervloet, E., Pluym, B. F. M., Cilissen, J., Köhlen, K., and Merkus, F. W. H. M. (1977). Propranolol serum levels during twenty-four hours. Clinical Pharmacology and Therapeutics, 22, 853-857.

Winkler, G. F., and Young, R. R. (1971). The control of essential tremor by propranolol. Transactions of the American Neurological Association, 96, 66-68.

Winkler, G. F., and Young, R. R. (1974). The efficacy of chronic propranolol therapy in action tremors of the familial, senile or essential varieties. New England Journal of Medicine, 290, 984-988.

Young, R. R., Growdon, J. H., and Shahani, B. T. (1975). Beta-adrenergic mechanisms in action tremor. New England Journal of Medicine, 293, 950-953. 